\title{
Evaluating the home isolation of COVID-19 patients in primary care
}

\author{
Zeynep Unus Yılmaz ${ }^{1}$, Sevgi Duman ${ }^{1 *}$, Güzin Zeren Öztürk ${ }^{1}$, Hacı Mustafa Özdemir², Gözde \\ Günindi Hogan ${ }^{1}$, ElifKarataş ${ }^{1}$
}

\begin{abstract}
Background: This study aims to evaluate the effectiveness of home isolation and medical follow-up by analyzing data collected over the phone from isolated individuals.

Methods: A cross-sectional phone-based survey designed to evaluate the home isolated COVID-19 suspected patients at the Şişli Hamidiye Etfal Family Health Center in Istanbul city between 16th March 5th May 2020. A semistructured questionnaire and the universal sampling technique were recruited to collect data about the sociodemographic and the COVID-19 related laboratory and clinical findings. The SPSS for Windows program was used to perform a univariate and bivariate statistical analysis. The Statistical alpha significance level was accepted at less than 0.05 .
\end{abstract}

Results: A total of 463 confirmed, probable, or suspected cases of COVID-19 took part in this study with a mean age of 35.38 干17.1 (range: 0-86 years). Tow-third 310 (67.0\%) underwent the PCR tests, and $67(21.6 \%)$ confirmed positive results. Moreover, one-third (159, 34.3\%) exposed to CT scans; however, 51(32.3\%) were compatible with COVID-19. The median age of individuals with PCR positive was 38 years. More than half $(40,59.7 \%)$ were males, compared to $27(40.3 \%)$ were females. There was no significant relationship between PCR positivity and pandemic period, age, or gender $(P=0.149 ; P=0.545 ; P=0.285)$, respectively. Although older individuals had a higher rate of CT scan compatible with COVID-19, the relation between increased age and COVID-19 compatible CT was found not to be statistically significant $(P=0.053)$. Moreover, there was significant relationship between CT scan positivity and coughing, the tobacco smoking and diabetes $(P=0.003 ; P=0.032 ; P=0.016)$, respectively.

Conclusion: Combining PCR, symptoms, and CT together doubles the likelihood of a correct diagnosis. Quarantined patients must be regularly monitored.

Keywords: COVID-19, Patients, Isolation, Primary Care, Istanbul, Turkey

\section{Background}

A new type of coronavirus, SARS-COV-2, was first isolated during an investigation into an outbreak of pneumonia cases of unknown etiology that occurred on 31st December 2019 in Wuhan, China [1]. The World Health Organization (WHO) named the disease caused by this virus COVID-19 on 11th February 2020 [2]. The world was not ready to face a global crisis in a unified manner. The virus spread rapidly in most countries of the world [3]. The WHO officially declared COVID-19 as a pandemic on the 11th of March 2020, the day when the first positive case was detected in Turkey [4]. Turkey was among the first countries that start preparing and planning early to control the spread of the virus and its impact. Turkey has adopted the filiation technique to prevent the spread of Coronavirus disease by cutting the chain of transmission by

*Correspondence: drsevgiduman@hotmail.com

${ }^{1}$ Family Medicine Depertmant, Şişli Hamidiye Etfal Research and Training Hospital, İstanbul, Turkey

A full list of author information is available at the end of the article systematically tracking and isolating vulnerable individuals who have been in contact with any confirmed cases. The peak level of COVID-19 in Turkey was reached 25 days after the first fatality was recorded on 11th April 2020 [5]. According to the 'COVID-19 (SARS-COV-2) Infection Guide' published by the Scientific Committee in the Ministry of Health in Turkey, the following groups were treated as definite cases and isolated at home for 14 days [6]; people who came from abroad, those who had come into contact with confirmed cases and people with a confirmed diagnosis. This process was controlled by phone calls made by family physicians to people in isolation, in line with the guidelines. These additional control measures started on 16 March 2020; their purpose was to assess individuals' condition, increase compliance with the isolation rules, and reduce the circulation of the virus, reducing the number of new cases [7]. This study aims to evaluate the effectiveness of home isolation, and medical follow-up was done for a sample of patients recorded in the primary health care services in the Şişli Hamidiye Etfal Family Health Center in Istanbul city, Turkey. 


\section{Methods}

Study population and sample

A retrospective and descriptive study designed to evaluate the isolated home COVID-19 confirmed, probable, or suspected cases in Istanbul city between March 16 and May 5, 2020. This study was conducted on patients registered in Şişli Hamidiye Etfal Family Health Center; is a public primary healthcare center located in the sisli city, the European side of Istanbul. It is a family health center with seven doctors and seven nurses, providing primary health care services to approximately 20,000 people.

\section{Inclusion and exclusion criteria}

All confirmed, probable, or suspected cases of COVID-19, both gender and all ages who were isolated at home, under treatment and following up by the family physicians over the phone between 1st and 30th April 2020, and willing to participate are included in the study. Patients who were unwilling to participate and those with missing data are excluded from the study.

\section{The sampling technique}

The universal sampling technique was recruited to collect data from all (confirmed, probable, or suspicious COVID-19 patients) who were already recorded at the Şişli Hamidiye Etfal Family Health Center, Istanbul, Turkey. Family physicians used the available data to contact patients directly via the phone during the regular follow-up to progress COVID-19 infection.

\section{Data collection tools}

Individuals isolated at home were followed up via phone calls. The respondents were asked to answer a total of 13 questions in four different parts and giving responses as either "Yes" or "No". The first section contained information about the participants' social and demographic characteristics, including citizenship number, age, and gender. The second section was about the participants' case types (confirmed, probable, or suspicious COVID-19 cases), nasopharyngeal PCR (Polymerase Chain Reaction) test results, computed tomography (CT) scan findings, treatment status, comorbidities, tobacco smoking, and the people with whom they live. In the third part, the focus was on the three main symptoms of COVID-19 (fever, cough, shortness of breath), length of the symptom, and whether the symptoms appeared in other family members or not. The fourth section contained information about compliance with specified quarantine rules, i.e., not leaving the house, not accepting visitors, being alone in a separate room to other members of the household, sufficiently ventilating the room, wearing a medical mask in all common areas of the house, cleaning the areas like WC/bathroom after each use, hand hygiene, separate use of household items such as plates, glasses, and towels.

\section{Statistical analysis}

The SPSS for Windows program was used for statistical analysis. Descriptive statistics of evaluation results are given as a number and percentage for categorical variables such as mean, standard deviation, and minimum, maximum for numerical variables. The differences between the rates of categorical variables in independent groups were tested with Chi-Square
Analysis. The correlated parameters were also evaluated by regression analysis. Statistical alpha significance level was accepted as $\mathrm{p}<0.05$.

\section{Results}

Characteristics of the participants

Out of 1150 eligible women, 906 were included in the study (response rate $60.4 \%)$. The mean age was $29.59( \pm 4.74$ years). Most of the respondents were high educated (75.2\%), housewives (86.1\%), nuclear family $(96.1 \%)$, and low-income $(\leq 4400 \mathrm{TL})$ families $(53.9 \%)$. Most of the respondents neither having a history of psychiatric disease $(95.9 \%)$ nor having a family member with a history of psychiatric disease (87.3 Out of 463 people who were followed up in isolation and defined as a confirmed, probable, or suspicious COVID-19 cases, 211 $(45.6 \%)$ of them were in contact with confirmed cases, 56 (12.1\%) were confirmed cases, and 196 (42.3\%) were suspicious cases. The average age of the individuals was 35.38 $\mp 17.1$ (0-86 years). More than half $(249,53.8 \%)$ of the followed-up patients were males, most diagnosed after the peak period $(290,63 \%)$, and the majority were living with their immediate families $(396,85.5 \%)$. About one-quarter (114, $24.62 \%$ ) of them reported at least one comorbidity and history of tobacco smoking $(103,22.2 \%)$ with an average of $16.19 \mp 12.3$ cigarettes per day in a range of 1-65 cigarettes daily (Table 1).

Table 1 Socio-demographic factors $(n=463)$

\begin{tabular}{|c|c|c|}
\hline Variables & Category & $\mathrm{N}(\%)$ \\
\hline \multirow[t]{3}{*}{$\begin{array}{l}\text { COVID-19 } \\
\text { cases }\end{array}$} & $\begin{array}{l}\text { Contact with confirmed } \\
\text { cases }\end{array}$ & $211(45.6)$ \\
\hline & Confirmed cases & $56(12.1)$ \\
\hline & Suspicious cases & $196(42.3)$ \\
\hline \multirow[t]{2}{*}{ Gender } & Male & $249(53.8)$ \\
\hline & Female & $214(46.2)$ \\
\hline \multirow{2}{*}{$\begin{array}{l}\text { Time } \\
\text { diagnosis }\end{array}$} & Before the peak & $173(37.0)$ \\
\hline & After the peak & $290(63.0)$ \\
\hline \multirow[t]{3}{*}{ Living situation } & Alone & $22(4.8)$ \\
\hline & $\begin{array}{l}\text { With their immediate } \\
\text { families }\end{array}$ & $396(85.5)$ \\
\hline & $\begin{array}{l}\text { With their extended } \\
\text { families }\end{array}$ & $45(9.7)$ \\
\hline \multirow[t]{2}{*}{ Co-morbidities } & No & $349(75.4)$ \\
\hline & Yes & $114(24.6)$ \\
\hline \multirow[t]{3}{*}{ Yes $(n=114)$} & $\begin{array}{l}\text { Having only one co- } \\
\text { morbidity }\end{array}$ & $82(17.7)$ \\
\hline & Having two co-morbidities & $26(5.6)$ \\
\hline & $\begin{array}{l}\text { Having three and more co- } \\
\text { morbidities }\end{array}$ & $6(1.3)$ \\
\hline \multirow[t]{5}{*}{$\begin{array}{l}\text { Co-morbidities } \\
(\mathrm{n}=114)\end{array}$} & $\begin{array}{l}\text { High Blood Pressure } \\
\text { (Hypertension) }\end{array}$ & $41(8.9)$ \\
\hline & Diabetic Disease & $26(5.6)$ \\
\hline & Heart disease & $7(1.5)$ \\
\hline & Lung disease & $35(7.6)$ \\
\hline & Others & $43(9.3)$ \\
\hline \multirow{2}{*}{$\begin{array}{l}\text { Tobacco } \\
\text { smoking }\end{array}$} & No & $360(77.8)$ \\
\hline & Yes & $103(22.2)$ \\
\hline
\end{tabular}


COVID-19 related symptoms and the associated factors Out of total patients, 79 (17.1\%) were symptomatic. Most of them presented with cough $(30.0 \%)$, shortness of breath $(19.5 \%)$, weakness $(11.1 \%)$, fever $(9.5 \%)$, and sore throat (8.4\%), respectively (Figure 1). Moreover, 18 (3.9\%) of the patient who was followed up in isolation had a fever which lasted for an average of 4.17干2.3 (1-7 days) days. Cough has lasted for an average of 8,43干9,6 (1-36 days) in 57 (12.3\%) patients. The long-lasting symptom was shortness of breath for an average of 20.53干19.4 (3-60 days).

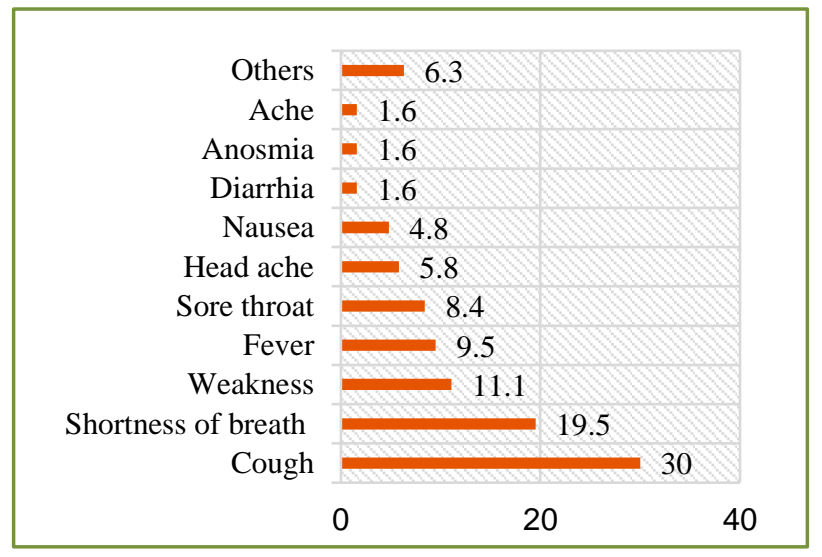

Figure 1 Frequency distribution of symptoms

Out of $310(67.0 \%)$ of the followed patients underwent PCR test, and about one-fifth $(67,21.6 \%)$ confirmed positive results. Moreover, one-third $(159,34.3 \%)$ exposed to CT scan; however, $51(32.3 \%)$ were compatible with COVID-19 (Figure 2)

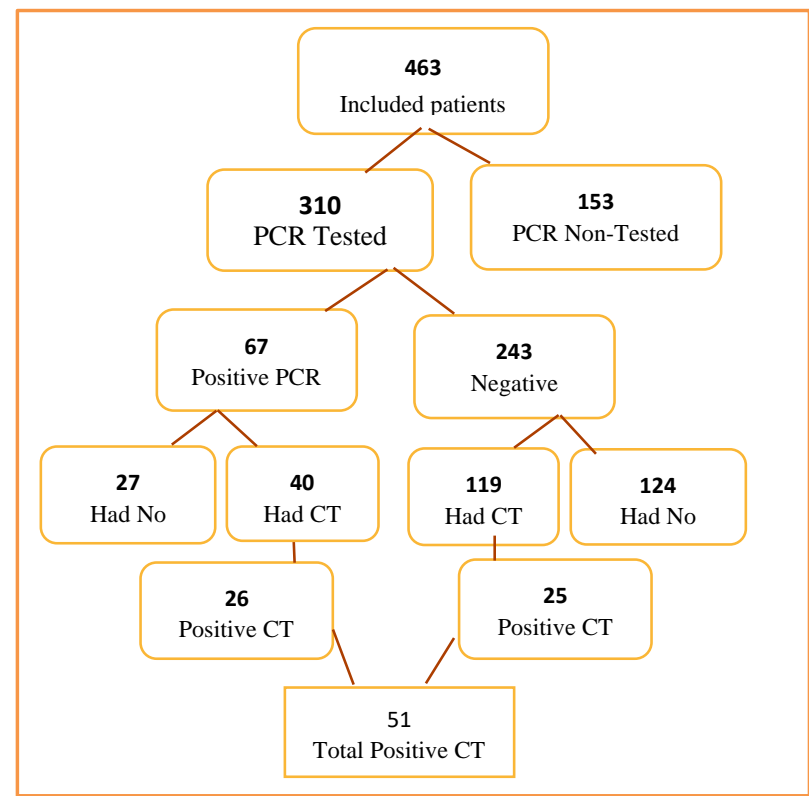

Figure 2 The flow chart of the included cases

Table 2 presents the relationship between the PCR results, CT findings, and the main symptoms associated with COVID-19. The relationship between having a cough and a PCR positive test was significant $(\mathrm{P}=0.003)$. About two-quarter $41(61.2 \%)$ of the PCR positive individuals were symptomatic, for which the most common symptom was cough $(19,28.4))$. Moreover, more than half $(28,54.9 \%)$ of the positive CT finding patients were symptomatic, for which the most common symptom was cough $(22,20.6 \%)$.
Compliance with isolation rules

During the lockdown period, most of the patients followed up in this study showed high compliance with the isolation rules. However, $21.2 \%$ of them left their house at least once, and $1.9 \%$ received visitors. Two-thirds, $65.4 \%$ followed social distancing rules; however, $43.8 \%$ did not wear masks when being in public areas. More than ninety percent of the patients were paying attention to ventilation rooms, cleanness at individual and family levels (Table 3).

Table 4 presents the relationship between PCR results and compliance with the isolation rules. Chi-square test showed that a patient who is going out of the house is significantly associated with positive PCR ( $\mathrm{p}<0.001)$. However, the patients who are staying alone in a separate room $(\mathrm{P}<0.001)$, using a medical mask $(\mathrm{p}<0.001)$, cares about toilet/bathroom hygiene $(\mathrm{P}=0.006)$, and those who separate use of items such as plates, Glasses, and Towels $(\mathrm{P}=0.015)$.

Table 5 presents the descriptive of comorbidities, tobacco smoking, and medication used in relation to PCR results. Out of 67 (\%) PCR positive patients, $12(27.0 \%)$ were hypertensive, 3 (23.0\%) chronic lung disease, 7 (\%) diabetic patients and 2() heart disease. When the co-morbidities were examined separately, there was a significant relationship between the hypertensive patients and the PCR positivity $(\mathrm{p}=0.021)$. Out of 67 (\%) PCR positive patients, 9 (13.4\%) were tobacco smokers. There was a significant relationship between smoking and PCR positivity $(\mathrm{p}=0.024)$. Out of 463 patients followed in this study, 91 (19.7\%) of them used medication. Most of them (67, $73.6 \%$ ) were PCR positive, while 24 (26.4\%) were PCR negative but had positive CT findings. Hydroxychloroquine, Oseltamivir, and Favipiravir were used to treat 91,18, 5 patients, respectively.

Association of sociodemographic and clinical variables with the positive PCR and CT

The median age of individuals with PCR positive was 38 years. More than half $(40,59.7 \%)$ were males, compared to 27 (40.3\%) were females. There was no significant relationship between PCR positivity and pandemic period, age, or gender ( $\mathrm{p}$ $=0.149 ; \mathrm{p}=0.545 ; \mathrm{p}=0.285)$, respectively. Although older individuals had a higher rate of CT scan compatible with COVID-19, the relation between increased age and COVID-19 compatible CT was found not to be statistically significant ( $\mathrm{p}=$ 0.053). Moreover, there was a significant relationship between $\mathrm{CT}$ scan positivity and tobacco smoking and diabetes $(\mathrm{p}=$ $0.032 ; \mathrm{p}=0.016$ ), respectively. However, analysis found no significant relationship between CT scan positivity and gender, hypertension, heart disease, lung disease $(\mathrm{p}=0.132 ; \mathrm{p}=0.214$; $\mathrm{p}=0.707 ; \mathrm{p}=0.093$ ), respectively.

\section{Discussion}

In this study, more than half $(59.7 \%)$ of patients with a positive PCR were males with a median age of 38 years, which is younger than that reported in the United States ( 48 years) by Stokes et al. [8] and that reported in China (49.6 years) by Yang et al. [9]. In our sample, the median age was younger than earlier studies because the PCR positive patients consisted of only those who were followed up during home-based selfisolation and did not require hospitalization. 
Table 2 Association of PCR results and CT findings with main COVID-19 symptoms

\begin{tabular}{lllllllll}
\hline Symptoms & Category & PCR +ve & PCR -ve & P & Category & CT +ve & CT -ve & P-value \\
\hline \multirow{3}{*}{ Total observation } & & $\mathrm{N}(\%)$ & $\mathrm{n}(\%)$ & & & $\mathrm{n}(\%)$ & $\mathrm{n}(\%)$ & \\
Fever & $\mathrm{N}=310$ & $67(21.6)$ & $243(78.4)$ & & $\mathrm{N}=158$ & $51(32.3)$ & $107(67.7)$ & \\
& Yes & $6(9.0)$ & $10(4.1)$ & 0.113 & Yes & $4(7.8)$ & $7(6.5)$ & 0.747 \\
Cough & No & $61(91.0)$ & $233(95.9)$ & & No & $47(92.2)$ & $100(93.5)$ & \\
& Yes & $19(28.4)$ & $32(13.2)$ & 0.003 & Yes & $22(20.6)$ & $13(25.5)$ & 0.485 \\
Shortness of breath & No & $48(71.6)$ & $211(86.8)$ & & No & $85(79.4)$ & $38(74.5)$ & \\
& Yes & $6(9.0)$ & $30(12.3)$ & 0.443 & Yes & $7(13.7)$ & $21(19.6)$ & 0.364 \\
& No & $61(91.0)$ & $213(87.7)$ & & No & $44(86.3)$ & $86(80.4)$ & \\
\hline
\end{tabular}

PCR: Polymerase Chain Reaction; CT: computed tomography

Table 3 Compliance with isolation rules $(\mathrm{n}=463)$

\begin{tabular}{|c|c|c|}
\hline Isolation rules & $\begin{array}{l}\text { Yes } \\
\mathrm{N}(\%) \\
\end{array}$ & $\begin{array}{l}\text { No } \\
\mathrm{N}(\%)\end{array}$ \\
\hline Leaving home at least once & $98(21.2)$ & $365(78.8)$ \\
\hline Accepted visitors & $9(1.9 \%)$ & $454(98.1)$ \\
\hline Obeying to the social distancing rules & $303(65.4)$ & $160(34.6)$ \\
\hline $\begin{array}{l}\text { Ventilating the room at the } \\
\text { recommended frequency }\end{array}$ & $452(97.6)$ & $11(2.4)$ \\
\hline Wearing masks in the common areas & $260(56.2)$ & $203(43.8)$ \\
\hline $\begin{array}{l}\text { Cleaning the common areas such as } \\
\text { the bathroom after each use }\end{array}$ & $419(90.5)$ & $44(9.5)$ \\
\hline $\begin{array}{l}\text { Paying attention to the separate use of } \\
\text { household items such as plates, } \\
\text { glasses, and towels }\end{array}$ & $427(92.2)$ & $36(7.8)$ \\
\hline
\end{tabular}

Moreover, the scientific literature explains the increase in PCR positivity in men due to more concentrations of angiotensinconverting enzyme 2 (ACE2) in their blood than in women. The abundance of ACE2 allows a higher level of the coronavirus to be transmitted to healthy cells, making them more susceptible to COVID-19. The prevalence rate of tobacco smoking is higher among men than women, which increases their risk of lung disease [10], while women have a high level of immunity due to an increase in the $\mathrm{X}$ chromosome [11]. Previous studies found that women are more committed to protection standards from the coronavirus than men $[12,13,14]$.

Furthermore, men are more commonly employed in jobs outside the home and most likely subjected to less social distancing rules. At the time of this study, out of 310 patients who underwent to PCR test, $67(21.6 \%)$ returned a positive result. Our findings rated higher than the global percent (7.0\%) [15] and the official Turkish rate (6.3\%) [16]. This difference is because the individuals who have been followed up all considered to be likely causes.

Likewise to our findings, several studies [8, 9,17,18 ] reported that cardiovascular disease (hypertension and coronary heart disease), diabetes, and chronic lung diseases are the most common comorbidities related to COVID-19 PCR positive cases. Stokes et al. [8], in their report, found that cardiovascular disease, diabetes, and chronic lung diseases rated 32\%, 32\%, and $18 \%$, respectively, among United States PCR positive cases. Yang et al. [9], in their meta-analysis, reported that hypertension $(21.1 \%)$, diabetes $(9.7 \%)$, and cardiovascular diseases $(8.4 \%)$ are in the top list of PCR positive related comorbidities. Zhou et al. [17] also reported hypertension, diabetes, and coronary heart disease diagnosed in 30\%, 19\%, and $8 \%$, of the PCR positive cases, respectively.

In the bivariate analysis, we found a statistically significant relationship between hypertension and PCR positive patients. Wang et al. [18] found that the coronavirus worsens with high blood pressure. More than $26.0 \%$ of the total population have hypertension [19] and common among adults [20]. Moreover, Lippi et al. [21] have stressed that the mechanism of action of the enzyme ACE2 explains its role in explaining the relationship between high blood pressure and infection with COVID-19. Among the 67 PCR positive studied patients, 9 (13.4\%) had a positive history of tobacco smoking; however, the rate was lower than the national rate of tobacco smoking (29.3\%) reported in 2018 [22]. Zhang et al. [19, 23] reported a rate of $7.0 \%$ tobacco smokers among the COVID-19 patients, which is lower than the rate of adult smoking prevalence $(27.7 \%)$ in China [24]. Moreover, in our study, we found a significant relationship between non-tobacco smoking and PCR positivity $(\mathrm{p}=0.024)$. Unlike our results, Zhao et al. [25] and Zhang et al. [23] found a statistically significant relationship between tobacco smoking and the severity of COVID-19 disease among patients. Different findings were reported by Vardavas et al. [26], who calculated a relative risk indicating a non-significant relationship between tobacco smoking and the severity of COVID-19. However, Simons et al. [27] concluded that there was significant uncertainty in the relationship between tobacco smoking and COVID-19 results. The symptoms of COVID-19 occurred in most cases approximately 4 to 5 days after exposure. Similarly, Li et al. [28] reported a mean incubation period of 5.2 days in China. Asymptomatic infections frequency is unknown, but several studies in various settings show that they are common.

Mizumoto et al. [29] estimated the asymptomatic proportion among the Japanese people was $17.9 \%$. Our findings showed that $26(38.8 \%)$ of the PCR-positive individuals were asymptomatic. However, the most common symptom was cough. Similarly to previous studies, the symptomatic cases presented with fever (43.0\%), cough $(50.0 \%)$ and/or shortness of breath $(29.0 \%)$, upper respiratory symptoms (20.0\%), headache $(34.0 \%)$, myalgia $(36.0 \%)$, diarrhea $(19.0 \%)$, nauseavomiting $(12.0 \%)$ and loss of sense of smell or taste (10.0\%) are also common $[4,30]$.

The American Association of Infectious Diseases (IDSA) recommends testing nasopharyngeal specimens instead of the oropharyngeal specimen (or saliva) due to lower sensitivity to oropharyngeal specimens and lack data on the accuracy of saliva specimens [31]. 
Table 4 Relationship between PCR results and compliance with isolation rules $(\mathrm{n}=310)$

\begin{tabular}{|c|c|c|c|c|}
\hline Variables & Category & $\mathbf{P C R}+$ & PCR - & P-value \\
\hline & & $\mathrm{n}(\%)$ & $\mathrm{n}(\%)$ & \\
\hline Total observation & $\mathrm{N}=310$ & $67(21.6)$ & $243(78.4)$ & \\
\hline \multirow[t]{2}{*}{ Going Out of the house } & Yes & $4(6.0)$ & $69(28.4)$ & 0.000 \\
\hline & No & $63(94.0)$ & $174(71.6)$ & \\
\hline \multirow{2}{*}{ Visitor Acceptance } & Yes & $3(4.5)$ & $4(1.6)$ & 0.167 \\
\hline & No & $64(95.5)$ & $239(98.4)$ & \\
\hline \multirow[t]{2}{*}{ Staying alone in a separate room } & Yes & $60(89.6)$ & $148(60.9)$ & 0.000 \\
\hline & No & $7(10.4)$ & $95(39.1)$ & \\
\hline \multirow[t]{2}{*}{ The Ventilation of the Room } & Yes & $66(98.5)$ & $235(96.7)$ & 0.437 \\
\hline & No & $1(1.5)$ & $8(3.3)$ & \\
\hline \multirow[t]{2}{*}{ Using Medical Mask } & Yes & $56(83.6)$ & $119(49.0)$ & 0.000 \\
\hline & No & $11(16.4)$ & $124(51.0)$ & \\
\hline \multirow[t]{2}{*}{ Cleaning WC/bathroom } & Yes & $66(98.5)$ & $211(86.8)$ & 0.006 \\
\hline & No & $1(1.5)$ & $32(13.2)$ & \\
\hline \multirow[t]{2}{*}{ Hand hygiene } & Yes & $66(98.5)$ & $236(97.1)$ & 0.526 \\
\hline & No & $1(1.5)$ & $7(2.9)$ & \\
\hline \multirow[t]{2}{*}{ Separate use of items such as plates, Glasses, and Towels } & Yes & $67(100)$ & $223(91.8)$ & 0.015 \\
\hline & No & 0 & $20(8.2)$ & \\
\hline
\end{tabular}

Table 5 Descriptive of co-morbidities, tobacco smoking, and medication used in relation to PCR results

\begin{tabular}{llllll}
\hline Variables & Categories & PCR & & non PCR & Total \\
\hline Total observation & & Positive & Negative & N=153 & \\
$\mathrm{N}=463$ & & $\mathrm{~N}=67$ & $\mathrm{~N}=243$ & & \\
\hline Co-morbidities & Hypertension & $12(17.9)$ & $20(8.2)$ & $9(5.9)$ & 41 \\
& Chronic Lung Disease & $3(4.5)$ & $26(10.7)$ & $6(3.9)$ & 35 \\
& Diabetes & $7(10.4)$ & $13(5.3)$ & $6(3.9)$ & 26 \\
& Heart Disease & $2(3.0)$ & $4(1.6)$ & $1(0.7)$ & 7 \\
Healthy individuals & Others & $5(7.5)$ & $31(12.7)$ & $7(4.6)$ & 43 \\
Tobacco Smoker & & $38(56.7)$ & $149(61.3)$ & $124(81.0)$ & 311 \\
Non-smokers & & $9(13.4)$ & $65(26.7)$ & $29(19.0)$ & 103 \\
Used medication & & $58(86.6)$ & $178(73.3)$ & $124(81.0)$ & 360 \\
Non used medication & & $67(100)$ & $24(9.9)^{*}$ & 0 & 91 \\
\hline
\end{tabular}

*Individuals with negative PCR results but positive CT.

Fang et al. [34] reported that among 51 patients hospitalized in China with fever or acute respiratory symptoms and ultimately a positive PCR test, the initial PCR test was negative in 15 patients $(29.0 \%)$, and they were subsequently diagnosed only after repeated tests.

Similarly, Lee et al. [35] found that the first nasopharyngeal test was $11 \%$ negative among 70 Singaporean patients. Long et al. [36] examined the rates of conversion from negative to positive NP SARS-CoV-2 RT-PCR. The authors found that $3.5 \%$ of the 626 patients retested who underwent repeated nasopharyngeal PCR tests within seven days of the first negative test in the USA were eventually found to be positive. The test's sensitivity will most likely depend on the type and quality of the sample, the duration of the disease during the test, and the specific assay. However, chest CT abnormalities were also identified before symptoms developed and even before PCR positivity was detected [37].

Chest CT scan is a vital component in the diagnostic algorithm for patients suspected of COVID-19 infection. However, it has limited sensitivity and negative predictive value after the onset of symptoms and is therefore not a reliable, independent tool to rule out COVID-19 infection [38].

In the context of the typical clinical presentation and exposure to other people with COVID-19, the CT scan features of viral pneumonia may be strong indicators for COVID-19 infection despite negative PCR results. In these cases, even though literature recommends repeated stick testing and patient isolation [38]. In Turkey, these cases were treated as positive cases of COVID-19 [39]. In this study, 24 patients with CT findings and symptom positivity were treated for COVID-19 even though their PCR results were negative.

Kenny and his colleagues [40] concluded that respiratory function decreased significantly among smokers and diabetics patients for ten years or more, with a clear association with a significant reduction in quality of life and impaired ability to exercise. Also, there was a suppression of the immune system by diabetes [41] and a negative effect of smoking on the lungs [42]. In this study, the positivity of CT findings was found to be associated with smoking and diabetes. Considering the results mentioned above, we believe that the evaluation of symptoms, PCR, and CT scan together in COVID-19 diagnosis will 
generally facilitate the diagnosis and should be evaluated simultaneously, especially in individuals with cough.

Patients suspected or confirmed with COVID-19 (including those waiting for test results) should stay at home and isolate themselves from other people and animals at home. It is suggested that the patient should be placed alone in a wellventilated room, leaving a distance of at least 1 meter (e.g., sleeping in a separate bed) if a separate room is not possible.

It is also recommended to limit the patient's movement at home and to minimize the shared space. If those who share a living space with these people need to be in the same room, the World Health Organization (WHO) recommends these people wear a medical mask [43]. It also recommends not allowing visitors, applying hand hygiene after any contact, and using disposable paper towels to dry hands. If these are not available, using clean towels and changing them frequently, using special food utensils for the patient, and cleaning the surfaces where the patient touches the room, for example, bathrooms and toilets, with hypochlorite containing $0.1 \%$ sodium are also recommended. In order to be released from home isolation, a negative PCR result must be obtained at least twice from patients, with the samples being taken 24 hours apart [44].

This study complaint of some limitations. Since only phone calls are used to follow-up of isolation patients, the data are based on the verbal statements of the patients. This situation creates a limitation in terms of the accuracy of the information.

\section{Policy implication}

Given the instructions and the guide prepared in Turkey $[6,7,16]$, the recommendations of the World Health Organization and the Center for Disease Control, the health status of the isolated individuals were followed up. All data in this study were recorded during the first call to patients. Some of the home isolation patients were not compliant with the isolation rules at the time of the first call because they have difficulty adapting to the various aspects of quarantine. However, the subsequent calls showed that patients' compliance had increased in almost all instances. It was also observed that individuals with PCR positivity had higher levels of compliance with the isolation rules. This study indicated two reasons for the increased compliance with the isolation rules found in the subsequent phone interviews; the patients might become more are aware of the seriousness of the disease and better understand the severity of the disease due to their treatment; and the role of the regular follow-up of the patients by phone.

\section{Conclusion}

This study found that men are more commonly infected with COVID-19 than women. Patients with a positive history of chronic diseases, especially hypertension, are more likely to contract the disease. Moreover, it was determined that the combination of PCR tests, symptoms, and CT scans would increase the likelihood of a correct diagnosis. Although it increases the workload of family physicians and public health specialists, the continued observation and follow-up of the quarantined COVID-19 patients increase their compliance with the isolation regulations. Moreover, to reduce the workload of family doctors and public health professionals, it is recommended that initial contact with patients in home isolation be made by a trained health professional.
Abbreviation

COVID-19: Coronavirus; PCR: Polymerase Chain Reaction; CT: Computed Tomography; SARS-CoV: Severe Acute Respiratory Syndrome; WHO: The World Health Organization; CDC: Centers for Disease Control and Prevention; ACE: Angiotensin-Converting Enzyme; IDSA: American Association of Infectious Diseases

\section{Declaration}

Acknowledgment

We would like to thank the Family physicians at the Şişli Hamidiye Etfal Family Health Center for their contribution to the follow-up of isolation patients. We would like to thank all the participants of the survey.

Funding

The authors received no financial support for their research, authorship, and/or publication of this article.

Availability of data and materials

Data will be available by emailing drsevgiduman@hotmail.com.

Authors' contributions

Güzin Zeren Öztürk (GZÖ) and Sevgi Duman (SD) were the designers of the study, coordinating all aspects of the research and drafting and reviewing the article. Zeynep Unus Yllmaz and Gözde Günindi Hogan (ZUY, GGH) contributed to the analysis and interpretation of the study and the article's writing. Hacı Mustafa Özdemir (HMÖ) contributed to the study's concept, arrangement, and final approval. Sevgi Duman (SD) and Elif Karataş (EK) contributed to data collection. All authors have read and approved the final version of the manuscript.

Ethics approval and consent to participate

We conducted the research following the Declaration of Helsinki. The ethical protocol was approved by Health Sciences University Şişli Hamidiye Etfal Health Application and Research Centre Ethics Committee with approval number 2759 on 5 May 2020, Istanbul, Turkey.

\section{Consent for publication}

Not applicable

\section{Competing interest}

The authors declare that they have no competing interests.

\section{Open Acces}

This article is distributed under the terms of the Creative Commons $\begin{array}{llll}\text { Attribution } & 4.0 & \text { International License }\end{array}$ (http://creativecommons.org/licenses/by/4.0/), which permits unrestricted use, distribution, and reproduction in any medium, provided you give appropriate credit to the original author(s) and the source, provide a link to the Creative Commons license, and indicate if changes were made. The Creative Commons Public Domain Dedication waiver (http://creativecommons.org/publicdomain/zero/1.0/) applies to the data made available in this article unless otherwise stated.

Author Details

${ }^{1}$ Family Medicine Department, Şişli Hamidiye Etfal Research and Training Hospital, İstanbul, Turkey. ${ }^{2}$ Department of Orthopedics and Traumatology, Şişli Hamidiye Etfal Research and Training Hospital, İstanbul, Turkey.

\section{Article Info}

Received: 28 January 2021

Accepted: 10 April 2021

Published: 10 May 2021 


\section{References}

1. Gorbalenya AE, Baker SC, Baric RS, de Groot RJ, Drosten C, Gulyaeva AA, et al. The species Severe acute respiratory syndrome-related coronavirus: classifying 2019-nCoV and naming it SARS-CoV-2. Nat Microbiol. 2020;5(4):536-44. DOI: $10.1038 / \mathrm{s} 41564-020-0695-\mathrm{z}$

2. WHO, Coronavirus disease (COVID-19) situation reports 2020. Available from: https://www.who.int/docs/defaultsource/coronaviruse/situation-reports/20200312-sitrep-52-covid19.pdf?sfvrsn=e2bfc9c0_4 [Accessed on 12 May 2020].

3. Ali Jadoo SA. Was the world ready to face a crisis like COVID19? Journal of Ideas in Health 2020 ;3(1):123-4. https://doi.org/10.47108/jidhealth.Vol3.Iss1.45

4. WHO Director-General's opening remarks at the media briefing on COVID-19 - 11 March 2020. Available from: https://www.who.int/director-general/speeches/detail/whodirector-general-s-opening-remarks-at-the-media-briefing-oncovid-19---11-march-2020 [Accessed on 12 May 2020].

5. Demirtaş T, Tekiner H. Filiation: a historical term the COVID-19 outbreak recalled in Turkey. Erciyes Med J. 2020; 42(3): 354-8. https://doi.org/10.14744/etd.2020.54782

6. The Republic of Turkey, Ministry of Health, General Directorate for Public Health, COVID-19 (SARS-CoV-2 Infection) Guide, Study of Scientific Board; April 14th, 2020. Available from: https://hsgm.saglik.gov.tr/depo/birimler/goc_sagligi/covid19/rehb er/COVID-19_Rehberi20200414_eng_v4_002_14.05.2020.pdf [Accessed on 12 May 2020].

7. Bilimsel Danışma Kurulu Çalışması. COVID-19 (SARS-CoV-2 enfeksiyonu) temaslı takibi, salgın yönetimi, evde hasta izlemi ve filyasyon. 2020; Available from: https://covid19.saglik.gov.tr/Eklenti/40043/0/covid19rehberitemaslitakibievdehastaizlemivefilyasyonpdf.pdf

8. Stokes EK, Zambrano LD, Anderson KN, Marder EP, Raz KM, El Burai Felix S, et al. Coronavirus Disease 2019 Case Surveillance - United States, January 22-May 30, 2020. MMWR Morb Mortal Wkly 2020;69(24):759-65. http://dx.doi.org/10.15585/mmwr.mm6924e2external icon

9. Yang J, Zheng Y, Gou X, Pu K, Chen Z, Guo Q, et al. Prevalence of comorbidities and its effects in patients infected with SARSCoV-2: a systematic review and meta-analysis. Int $\mathrm{J}$ Infect Dis. 2020 May;94:91-95. doi: 10.1016/j.ijid.2020.03.017.

10. Cai H. Sex difference and smoking predisposition in patients with COVID-19. Lancet Respir Med. 2020 Apr;8(4):e20. doi: 10.1016/S2213-2600(20)30117-X

11. Gagliardi MC, Tieri P, Ortona E, Ruggieri A. ACE2 expression and sex disparity in COVID-19. Cell Death Discov. 2020;6(1):12.

12. Ali Jadoo SA, Alhusseiny A, Yaseen S, Al-Samarrai M, Al-Rawi R, Al-Delaimy A, Abed M, Hassooni H. Knowledge, attitude, and practice toward COVID-19 among Iraqi people: a web-based cross-sectional study. Journal of Ideas in Health 2020; 3(Special2):258-65. https://doi.org/10.47108/jidhealth.Vol3.IssSpecial\%202.59

13. Ali Jadoo SA, Dastan I, Al-Samarrai M, Yaseen S, Abbasi A, Alkhdar H, Al Saad M, Danfour O. Knowledge, attitude, and practice towards COVID-19 among Syrian people resident in Turkey. Journal of Ideas in Health 2020; 3(Special2):278-85. https://doi.org/10.47108/jidhealth.Vol3.IssSpecial2.61

14. Ali Jadoo SA, Danfour O, Zerzah M, Abujazia M, Torun P, Alsamarrai M, Yaseen S. Knowledge, attitude, and practice towards
COVID-19 among Libyan people- a web-based cross-sectional study. Journal of Ideas in Health 2021;4(Special1):348-56. https://doi.org/10.47108/jidhealth.Vol4.IssSpecial1.97

15. COVID-19 Coronavirus Pandemic, https://www.worldometers.info/coronavirus/ [Accessed on 6 July 2020].

16. Republic of Turkey Ministry of Health, Current Situation in Turkey, https://covid19.saglik.gov.tr/[Accessed on 6 July 2020].

17. Zhou F, Yu T, Du R, Fan G, Liu Y, Liu Z, et al. Clinical course and risk factors for mortality of adult inpatients with COVID-19 in Wuhan, China: a retrospective cohort study. Lancet. 2020 Mar 28;395(10229):1054-1062. doi: 10.1016/S0140-6736(20)30566-3.

18. Wang B, Li R, Lu Z, Huang Y. Does comorbidity increase the risk of patients with COVID-19: evidence from meta-analysis. Aging (Albany NY). 2020 Apr 8;12(7):6049-6057. doi: 10.18632/aging.103000.

19. Kearney PM, Whelton M, Reynolds K, Muntner P, Whelton PK, He J. Global burden of hypertension: analysis of worldwide data. Lancet. 2005 Jan 15-21;365(9455):217-23. doi: 10.1016/S01406736(05)17741-1.

20. Schiffrin EL, Flack JM, Ito S, Muntner P, Webb RC. Hypertension and COVID-19. Am J Hypertens. $2020 \mathrm{Apr}$ 29;33(5):373-374. doi: 10.1093/ajh/hpaa057.

21. Lippi G, Wong J, Henry BM. Hypertension in patients with coronavirus disease 2019 (COVID-19): a pooled analysis. Pol Arch Intern Med. 2020 Apr 30;130(4):304-309. doi: 10.20452/pamw.15272.

22. WHO global report on trends in prevalence of tobacco smoking 2000-2025, second edition. Geneva: World Health Organization. Available from: https://www.who.int/publications/i/item/whoglobal-report-on-trends-in-prevalence-of-tobacco-use-2000-2025third-edition [Accessed on 12 March 2021]

23. Zhang JJ, Dong X, Cao YY, Yuan YD, Yang YB, Yan YQ, et al Clinical characteristics of 140 patients infected with SARS-CoV-2 in Wuhan, China. Allergy. 2020 Jul;75(7):1730-1741. doi: 10.1111/all.14238.

24. China Center for Disease Control and Prevention 2015 China Adult Tobacco Survey Report. Beijing, 2015. Available from: http://www.tcrc.org.cn/UploadFiles/201603/318/201603231215175500.pdf [Accessed on 12 March 2021]

25. Zhao Q, Meng M, Kumar R, Wu Y, Huang J, Lian N, et al. The impact of COPD and smoking history on the severity of COVID19: A systemic review and meta-analysis. J Med Virol. 2020 Oct;92(10):1915-1921. doi: 10.1002/jmv.25889

26. Vardavas CI, Nikitara K. COVID-19 and smoking: A systematic review of the evidence. Tob Induc Dis. 2020 Mar 20;18:20. doi: $10.18332 /$ tid/119324

27. Simons D, Shahab L, Brown J, Perski O. The association of smoking status with SARS-CoV-2 infection, hospitalization and mortality from COVID-19: a living rapid evidence review with Bayesian meta-analyses (version 7). Addiction. 2020 Oct 2:10.1111/add.15276. doi: 10.1111/add.15276.

28. Li Q, Guan X, Wu P, Wang X, Zhou L, Tong Y, et al. Early transmission dynamics in Wuhan, China, of novel coronavirusinfected pneumonia. N Engl J Med. 2020;382(13):1199-207. doi: 10.1056/NEJMoa2001316.

29. Mizumoto K, Kagaya K, Zarebski A, Chowell G. Estimating the asymptomatic proportion of coronavirus disease 2019 (COVID19) cases on board the Diamond Princess cruise ship, Yokohama, 
Japan, 2020. Euro Surveill. 2020 Mar;25(10):2000180. doi: 10.2807/1560-7917.

30. Guan W, Ni Z, Hu Y, Liang W, Ou C, He J, et al. Clinical characteristics of coronavirus disease 2019 in China. N Engl J Med. 2020;382(18):1708-20. DOI: 10.1056/NEJMoa2002032

31. Hanson KE, Caliendo AM, Arias CA, Hayden MK, Englund JA, Lee MJ, et al. The Infectious Diseases Society of America Guidelines on the Diagnosis of COVID-19: Molecular Diagnostic Testing. Clin Infect Dis. 2021 Jan 22:ciab048. doi: 10.1093/cid/ciab048.

32. Ai T, Yang Z, Hou H, Zhan C, Chen C, Lv W, et al. Correlation of Chest CT and RT-PCR Testing for Coronavirus Disease 2019 (COVID-19) in China: A Report of 1014 Cases. Radiology. 2020 Aug;296(2): E32-E40. doi: 10.1148/radiol.2020200642.

33. Yang Y, Yang M, Yuan J, Wang F, Wang Z, Li J, et al. Laboratory Diagnosis and Monitoring the Viral Shedding of SARS-CoV-2 Infection. The Innovation2020;1(3):1-6. DOI:https://doi.org/10.1016/j.xinn.2020.100061

34. Fang Y, Zhang H, Xie J, Lin M, Ying L, Pang P, Ji W. Sensitivity of Chest CT for COVID-19: Comparison to RT-PCR. Radiology. 2020 Aug;296(2): E115-E117. doi: 10.1148/radiol.2020200432.

35. Lee TH, Junhao Lin R, Lin RTP, Barkham T, Rao P, Leo YS, Chien Lye D, Young B; National Centre for Infectious Diseases COVID-19 Outbreak Research Team. Testing for SARS-CoV-2: Can We Stop at 2? Clin Infect Dis. 2020 Nov 19;71(16):22462248. doi: 10.1093/cid/ciaa459.

36. Long DR, Gombar S, Hogan CA, Greninger AL, O'Reilly-Shah V, Bryson-Cahn C, et al. Occurrence and timing of subsequent severe acute respiratory syndrome coronavirus 2 reverse-transcription polymerase chain reaction positivity among initially negative patients, Clinical Infectious Diseases 2021;72, (2):323-326, https://doi.org/10.1093/cid/ciaa722
37. Bernheim A, Mei XM, Huang M, Yang Y, Fayad ZA, Zhang N, et al. Chest CT Findings in Coronavirus Disease-19 (COVID-19): Relationship to Duration of Infection. Vol. 19. 2020. https://doi.org/10.1148/radiol.2020200463

38. Xie X, Zhong Z, Zhao W, Zheng C, Wang F, Liu J. Chest CT for Typical Coronavirus Disease 2019 (COVID-19) Pneumonia: Relationship to Negative RT-PCR Testing. Radiology. 2020 Aug;296(2): E41-E45. doi: 10.1148/radiol.2020200343.

39. Republic of Turkey Ministry of Health, Covid-19 Adult Treatment Algorithm, https://covid19bilgi.saglik.gov.tr/depo/algoritmalar/COVID19PLKACILHASTAYONETIMI.pdf [Accessed on 02 July 2020].

40. Kinney GL, Black-Shinn JL, Wan ES, Make B, Regan E, Lutz S, et al. Pulmonary function reduction in diabetes with and without chronic obstructive pulmonary disease. Diabetes Care. 2014 Feb;37(2):389-95. doi: 10.2337/dc13-1435.

41. Donath MY, Dinarello CA, Mandrup-Poulsen T. Targeting innate immune mediators in type 1 and type 2 diabetes. Nat Rev Immunol. 2019;19(12):734-46. https://doi.org/10.1038/s41577019-0213-9

42. Newcomb PA, Carbone PP. The health consequences of smoking. Cancer. Med Clin North Am. 1992 Mar;76(2):305-31. doi: 10.1016/s0025-7125(16)30355-8.

43. World Health Organization. (2020). Advice on the use of masks in the context of COVID-19: interim guidance, 6 April 2020. World Health Organization. https://apps.who.int/iris/handle/10665/331693.

44. World Health Organization. (2020). Home care for patients with COVID-19 presenting with mild symptoms and management of their contacts: interim guidance, 17 March 2020. World Health Organization. https://apps.who.int/iris/handle/10665/331473. 